Vućo accuses prewar Yugoslavia of allowing agricultural prices to be dictated by foreign commodity exchanges. But he says that when the government divorced internal from external prices, it was done at the expense of the consumer. What does he want? The worst problem was the high peasant indebtedness, for debtors always suffer in times of deflation. The government proclaimed a moratorium for peasants, but Vućo claims that this was done for party-political reasons.

Criticizing Vućo's approach does not mean belittling either the magnitude of the problem or the degree of suffering involved. However, the problems are sufficiently important to deserve a more serious treatment.

The book contains a summary in English, but the translation is so bad that some passages are almost incomprehensible.

LJUBo SIRC

University of Glasgow

\title{
DǓRZHAVNO PRAVO NA NARODNA REPUBLIKA BŬLGARIIA. By Boris Spasov and Angel Angelov. 2nd revised edition. Sofia: Nauka i izkustvo, 1968. 515 pp. $1.87 \mathrm{lv}$.
}

Boris Spasov and Angel Angelov, professors of law at the University of Sofia and prolific legal writers, prepared a comprehensive discussion of the law of the state of the People's Republic of Bulgaria as early as 1959, when they first published their work based on university lectures. Three years later they put into print a more serious work on the subject (1962, $498 \mathrm{pp}$.), and it was translated into Russian. In 1968 the authors revised their study and enlarged it to 515 pages. As they indicate in the preface to this second edition, they intend it to serve as a textbook for law students and government officials, and it reflects the legislation effective June 1, 1967. However, a "Note of the Authors" at the end of the book (p. 515) explains that various changes in the field of "Basic Rights and Duties of Citizens of the P. R. of Bulgaria" have not been considered because they occurred when the book was already at the press.

The material is grouped into thirteen chapters, which deal with the meaning of the term "the Bulgarian law of the state"; the Constitution of the country; the constitutional set-up; the electoral system; the socioeconomic structure; territory, territorial sovereignty, and territorial division; the purpose, kinds, and systems of state organs (agencies); the National Assembly; the Presidium of the National Assembly; central organs of the state administration; local agencies of state power and state administration; courts and the Office of the Government Attorney; and the legal status of citizens.

The authors repeatedly emphasize "the influence of Soviet legal science and experience" in the shaping and development of Bulgarian constitutional law and the constitutional structure of the country. Two topics are of special interest-the adoption of the 1947 Dimitrov Constitution, its changes, and the drafting of a new "socialist constitution," and the role and status of the Bulgarian Communist Party within the legal system and state apparatus.

The authors admit that the various changes in the present Constitution were made improperly and that the Constitution makes no reference to socialism (p. 62). Since 1959 the National Assembly has three times appointed special constitutional commissions to draft a new text, but still without results. Furthermore, great confusion exists regarding the Communist Party, since there is no legislative regulation concerning its status and role. The party imposes its will directly 
through its own decrees or indirectly through joint resolutions of the party and the Council of Ministers (pp. 84, 382).

The book takes no comparative approach in discussing the various problems, applies a rather journalistic style, and lacks references to legal and other source material; furthermore, it contains no bibliography and offers only a few footnotes referring to political speeches, party resolutions, and the like. It also has no index. But it does present a comprehensive coverage of the present Bulgarian law of the state, and is thus a valuable contribution and source of information for students of Bulgarian law.

IVAN Sipkov

European Law Division, Library of Congress

\section{THE SHADOW OF THE CRESCENT: THE RENAISSANCE IMAGE OF} THE TURK (1453-1517). By Robert Schwoebel. New York: St. Martin's Press, 1967. xiv, 257 pp.

"The purpose of this book," the author informs his readers in the preface, "is to examine the western attitudes towards the Ottoman Turks in the critical years 1453-1517." These years were indeed crucial for both Western and Ottoman history. They produced not only a large amount of anti-Ottoman propaganda in the West but also numerous plans-and in some cases even action-on the part of Christendom to stem the Muslim tide. In the Ottoman Empire these are roughly the years of the sultans Mehmed II (1451-81), Beyazid II (1481-1512), and Selim I (1512-20), during which the state expanded considerably, gained inner stability, and shaped its institutions. The Fall of Constantinople in 1453 made even such faraway courts as that of England realize that on the other end of the continent a new major power had risen that presented a serious challenge to the rest of Europe. After Luther's theses of 1517 shattered the unity of Western Christendom its attention turned to its own problems, and the problem of the Ottomans received less attention from the West. Consequently the starting and terminal dates selected for this study were well chosen, marking the limits of a distinct period in late Renaissance history.

Mr. Schwoebel's volume is well organized. The chapter headings clearly indicate the various aspects of the Western reaction to the Ottoman menace which the author has investigated. We learn how the news of the fall of Constantinople reached the West, how these and subsequent reports described the Turks most often in exaggerated and erroneous but occasionally amazingly correct fashion, and how the Western image of the Turks was formed. Different chapters describe the reaction of the popes and the church, the various European rulers, the nobles, poets, and public opinion to the new menace to their realm and faith. We are told what countermeasures were planned, why so many remained only plans, and why those that were undertaken failed.

The author devotes much of the book to the evaluation of his numerous and well-selected sources and to secondary works on the subject. Schwoebel takes great pains to explain his sources and to correct, at least to this reviewer's satisfaction, certain errors that have been repeated by other students of the subject. The work has other merits; for example, it explains convincingly the importance of the Battle of Belgrade (July 3-22, 1456) and the role that John of Capistrano played in the preparation of the city's defense and in the battle itself. 